\title{
Hopes Woven in Smoke: Reimagining Virgil's Aeneid in Irene Vallejo's El silbido del arquero
}

\author{
Daniel Nisa Cáceres ${ }^{1}$ [D $\cdot$ Rosario Moreno Soldevila ${ }^{1}$ (D)
}

Accepted: 15 November 2021 / Published online: 15 January 2022

(c) The Author(s) 2022

\begin{abstract}
This article investigates Irene Vallejo's 2015 novel El silbido del arquero, a narrative in the Virgilian tradition mostly inspired by Book IV of the Aeneid. We show how Vallejo reinterprets Dido and Aeneas's tragic love story by foregrounding minor characters, developing the setting, integrating popular subgenres and exploring communicative anxieties and gender issues. It is argued that patterns of dissatisfaction, self-delusion and disillusionment with human affairs ultimately collide with a message of hope voiced by the fictionalised Virgil.
\end{abstract}

Keywords Irene Vallejo · El silbido del arquero · Virgil · The Aeneid · Dido and Aeneas

The dawn of the twenty-first century has been aptly described as a new "Aetas Virgiliana [...] dominated by women" (Cox, 2011, 268): Margaret Drabble's The Seven Sisters (2002), A. S. Byatt's short story "The Pink Ribbon" (2003), Ursula Le Guin's Lavinia (2008) or Jo Graham's Black Ships (2008), to quote but a few outstanding works, represent different ways of conversing with Virgil: they offer original approaches to explore both our own selves and present-day society. Alongside these and other narratives, Irene Vallejo's more recent El silbido del arquero (2015) has started to attract critical attention. ${ }^{1}$ This paper offers a comprehensive critical

\footnotetext{
1 See Nisa Cáceres \& Moreno Soldevila 2020. No English translation of El silbido del arquero exists as of the publication date of this article. The title literally means 'the whistle of the bowman', or rather the sound of the 'arrow' itself. Irene Vallejo (Saragossa, Spain, 1979) studied Classics at the University of Saragossa and was awarded her PhD from the Universities of Saragossa and Florence. She has published several novels and books for young readers and is a well-known columnist in El Heraldo de Aragón and El País. Her captivating essay El infinito en un junco. La invención de los libros en el mundo antiguo (Vallejo Moreu, 2019), where she surveys the story of books in Greece and Rome with incursions in con-
}

Rosario Moreno Soldevila

rmorsol@upo.es

Daniel Nisa Cáceres

dniscac@upo.es

1 Universidad Pablo de Olavide, de Sevilla, Seville, Spain 
approach to Vallejo's novel by giving an insight into the trails of thwarted desire and the intractable human interactions that thoroughly permeate the whole story.

\section{A Polyphonic Novel}

El silbido del arquero rewrites and, to a large extent, resizes the ill-fated relationship between Elissa ${ }^{2}$ and Aeneas, as developed in Books I and IV of the Aeneid, from the Trojan hero's arrival at the Libyan shore to his departure and the queen's subsequent suicide. ${ }^{3}$ Odd chapters, entitled "Naufragio", "Sangre", "Amor", "Asedio", 4 are narrated in the first person (and in the present tense) by four point-of-view characters: Aeneas, Elissa, her younger sister Anna, and the love-god Eros. The headings of each subchapter clearly indicate the name of the narrator. ${ }^{5}$ Whereas the perspectives of Elissa and Aeneas are partial and incomplete, Anna's is much wider in scope, due to her peeping and eavesdropping proclivities; yet the knowledge she gains, or rather her ability to interpret that knowledge is hampered by her age. It is to be noted that Anna complements her usual first-person view with the second person (74-77; 94-97) when she addresses Iulus, Aeneas's son ${ }^{6}$ : when an adolescent explains the world to a child, the choice of discourse must be necessarily simplified and puerile (94). Virtual omniscience is reserved for Eros: unencumbered by any time, space or ethical considerations, he knows the actions, thoughts and feelings of all the characters inside out, including the fictionalised Virgil. Yet knowledge does not necessarily result in agency, insofar as his tremendous efforts to unite Elissa and Aeneas are futile. Eros is also a metafictive narrator who even suspects his own fictionality. ${ }^{7}$

This complex and polyphonic amalgam of sometimes discordant viewpoints definitely delves into a major theme of Virgil's Aeneid Book IV-the different interpretations of events made by Dido and Aeneas, which leads to tragedy and remorse. In fact, El silbido del arquero constantly explores contemporary language-based

\footnotetext{
Footnote 1 (continued)

temporary culture, has earned her well-deserved critical acclaim. El silbido del arquero is protected by copyright. Quotations from the novel are not included in the Creative Commons licence.

2 Vallejo uses the Phoenician name "Elisa" instead of Dido, the nickname the Libyans gave to the queen.

3 For the manifold literary afterlives of Dido and her love relationship with Aeneas, see Hardie (2014, 51-76). See Lida de Malkiel (1974) and Cristóbal (2002) for her presence in Spanish literature. See Farrell and Putnam (2010) for the reception of the Aeneid.

4 Shipwreck, Blood, Love, Siege. This quadripartite structure recalls the four chapters of Hermann Broch's The Death of Virgil (1945): "Water-The Arrival", "Fire-The Descent", "Earth-The Expectation" and "Air-The Homecoming".

5 Compared to the multiple third-person point-of-view characters of G. R. R. Martin's A Song of Ice and Fire novels (1996-), Vallejo's mostly first-person narrative is at once less mediated and more immediate, alternating between more personal and intimate (yet limited) degrees of world knowledge and selfknowledge.

6 “¿Me das la espalda? ¿Te agarras a los postes para trepar por la tapia? Al otro lado están los prisioneros nómadas. Uno de ellos podría sacar la mano y agarrarte...jasí! Vámonos antes de que te coja" (94). She engages in basic conversation through questions and imperatives, voicing or echoing their actions as well as his verbal and physical reactions before he utters his first words: "Boca. La boca" (137).

7 "En ciertos momentos de ebriedad provocada por el néctar y la ambrosía, tenemos la vertiginosa impresión de ser solo parte de los relatos humanos, pálidas abstracciones que dan sentido a sus historias" (208).
} 
anxieties and delusional-like beliefs, as well as cognitive dissonances arisen out of failed human rituals and the constraints of interdependence. However, the lovers are not the only conduit. Both Anna's preadolescent voice-who finds and loses her first and only friend (Iulus) — and Eros's — whose stratagems to bring the protagonists closer together fail, to his dismay, once and again-, amplify a general sense of dissatisfaction by presenting different unachieved alternative denouements to the main, canonical plot.

\section{Faithfulness to the Aeneid and Narrative Originality}

These alternative plotlines, glimpsed but unfulfilled, lay the foundation of the overarching narrative frame, in which Virgil rethinks the poem in a creative impasse. In fact, echoing Virgilian verses in their titles ("Sombras iban delgadas", "Una tierra bajo otro sol", "Si algún poder tiene mi canto"), ${ }^{8}$ Chapters II, IV and VI form a third-person narrative set many centuries after those legendary events in Carthage: they show Virgil as a character ${ }^{9}$ in his wanderings all over Rome in search of his lost inspiration. Ill and unable to write an epic poem for Augustus, his fears and general discomfort are epitomised by an unknown stalker who follows him like a shadow. Only in Chapter VII, "Asedio", does the poet start using the first person as intrahomodiegetic narrator, just like the other four point-of-view characters, after finding at last his own voice. And he tries-unsuccessfully - to interact with them. The final chapter ("Detened las aguas del olvido") ${ }^{10}$ is an epilogue told by Eros, who closes the novel after attending Virgil's funeral.

Paradoxically, Vallejo is both devoutly faithful to the Aeneid's Book IV and highly inventive. Not only are the main events preserved, but the reader can also, now and then, hear echoes, calques, overt and veiled translations of the epic poem, ${ }^{11}$

\footnotetext{
${ }^{8}$ Verg. Georg. 4.472 umbrae ibant tenues; Georg. 2.512 alio patriam quaerunt sub sole iacentem; Aen. 9.446 si quid mea carmina possunt.

9 For the long-standing tradition of Virgil as a character, see Baquero Goyanes (1984).

10 This title echoes a line of the Spanish Renaissance poet Garcilaso de la Vega: Égloga III, 16.

11 Sometimes Virgil's verses are translated or recreated in the same contexts: "una ensenada de aguas tan quietas que ni siquiera hemos necesitado amarras para anclar la nave" (9); see Verg. Aen. 1.168-169 hic fessas non vincula navis / ulla tenent, unco non alligat ancora morsu; "Es doloroso recordar Troya, reina"; Verg. Aen. 2.3 Infandum, regina, iubes renovare dolorem. In some other cases, Virgilian echoes are transposed to different narrative situations, acquiring a new meaning. For instance, Virgil's insomnia, described through the contrast between the silence of night and internal turmoil ("Es noche profunda, todo está callado, mis esclavos descansan tras el bregar del día. Sin embargo yo, tendido en el lecho me agito sin reposar; el rocío del sueño no acaricia mis ojos, el encuentro fantasmal me impide dormir", 203) recalls Dido's (Verg. Aen. 4.522-532 Nox erat et placidum carpebant fessa soporen...). After the siege, the Trojans point to the places where the fighting had taken place (Verg. Aen. 27-30 desertosque videre locos litusque relictum: / hic Dolopum manus, hic saevus tendebat Achilles; / classibus hic locus, hic acie certare solebant): in Carthage, Iulus plays the Trojan war with nuts and the deictic adverbs he repeats recall that famous passage: «Aquí está el tío Héctor-señala una nuez-. Aquí el tío Paris. Aquí el tío Deífobo. Aquí está el guerrero más fuerte: tú [...]. Aquí el abuelo Príamo mirando la guerra desde la muralla»(117-118). When Aeneas and the Trojans attack the nomadic tribes, Aeneas thinks: "regresamos oscuros, en la noche silenciosa, a través de las sombras" (74), echo of Verg. Aen. 6.268 Ibant obscuri sola sub nocte per umbram (Aeneas and the Sibyl in the underworld).
} 
as in Ursula Le Guin's Lavinia. ${ }^{12}$ Yet the story is amplified and changes are introduced, encompassing multiple perspectives, complexities in character development and further subplots integrating mystery, adventure and Anna's friendship with Iulus. Vallejo loosely draws on Virgil, fills in gaps or departs imaginatively from the epic poem, ultimately exploring untrodden narrative paths in terms of gender and genre.

\section{Beyond Virgilian Characters}

\section{Anna}

Vallejo's emphasis on characterisation expands and modulates both Anna and Iulus, Aeneas's son, also known as Ascanius. While Anna's age goes unmentioned by Virgil, Iulus is said to be a puer in the Aeneid, a young boy, and as such befriends Anna in the novel. However, while the roles she plays in the epic poem of love confidante and go-between suggest adulthood, Vallejo's character is not an adult, but a girl on the verge of reaching puberty. She dreads the oncoming changes, oppressed as she is by Carthage, a city caught in a creeping paralysis where no child is born other than gossip and slander. Yet she enjoys her friendship with Iulus as a chance to make up for a traumatic early childhood spent in Tyre. Simply called 'sister' in the Aeneid, her narrative counterpart is Elissa's half-sister, her father's illegitimate daughter mothered by a Tyrian witch. In order to resize her identity and to provide her with an uncanny halo as well as to somehow empower her, Vallejo transfers some of Dido's features and qualities to Anna by virtue of her origins. In the Aeneid, it is Dido who acts as a priestess, offering sacrifices to the gods and interpreting the auspices (Aen. 4.60-64; 509-521), receiving bad omens (4.452-455) and performing love magic (4.512-521). In the novel, however, it is Anna who performs these rites (30-32, 126-127), who receives bad auguries and is familiar with love witchcraft, thanks to her mother (100).

Likewise, Anna finds herself involved in a crime fiction subplot, a series of events absent in the epic poem. All four members of Elissa's High Council—who are themselves disputing her hand-distrust the Trojan hero from the very moment he arrives and confront the queen about her attachment to him. By having three councillors successively murdered, Vallejo also endows this political intrigue-swathed in mystery-with conventional elements inherent to detective and spy narratives. Aeneas, the newcomer, automatically becomes a scapegoat and is held suspect of the assassinations. It is only through the fortuitous agency of Anna, Elissa's sister, who overhears a conversation, that the metaphorical and literal obstruction in the novel is bypassed. Anna eavesdrops on "Malco el Escudo", ${ }^{13}$ the last surviving member of

\footnotetext{
${ }^{12}$ See Bugada (2019, 68-69). For Le Guin's rewriting of Virgil see, e.g., Cox (2011, 247-263), Cristóbal (2015), Cantó (2016) and Nisa Cáceres \& Moreno Soldevila (2020).

${ }^{13}$ Malco the shield of the queen. The other warrior-councillors are Elibaal the bow, Safat the dagger, Ahiram the dart (15).
} 
the High Council, and a stranger to whom he entrusts the assassination of Aeneas (162-166). It could be argued that, as Gaylin points out with regard to the female narrator in Wilkie Collins's The Woman in White, Anna's “eavesdropping represents a double transgression: she oversteps the boundaries of proper ladylike behavior in her illicit listening and in assuming narrative agency-power over other people's stories and identities" (2004, 22). Anna reveals the secret to Elissa, who eventually takes her revenge on her treacherous councillor (190-191). However, despite providing closure to this subplot of political scheming and violence, Anna's agency shows itself to be totally limited, as it fails to ensure Aeneas's proper understanding of her yearning for a new life away from the maladies of Carthage: as a priestess of the Punic god Eshmun, she delivers a warning oracle to the hero (175-176), hoping that he will take her and her sister out of Carthage. With an elegant flourish of unprecedented dramatic irony, Aeneas misinterprets Anna and leaves her behind, inadvertently thwarting her desires (174-181).

\section{Elissa}

Since Antiquity, Troy has symbolised the horrors of war and its consequences, personified by the Trojan women. ${ }^{14}$ In fact, it is not infrequent to find modern theatrical adaptations of Euripides's and Seneca's Troades set in contemporary conflicts. ${ }^{15}$ Aeneas carries Troy with him, since he brings not only its gods (the Penates) and its people, but also war and doom to Carthage and Latium. When Elissa first encounters him, she perceives the stamp of devastation: "Lleva todavía el incendio en sus ojos" (24), ${ }^{16}$ an ambiguous, ominous remark. He brings the fires of war and love, the fires in which she will burn. When Carthage is about to be taken by Iarbas, Elissa broods over the future that awaits her as a hostage, in terms that recall Andromache's words in the Iliad: "Siempre he compadecido la suerte de las mujeres que se convierten en botín de guerra y deben amasar el pan, acarrear el agua y compartir el lecho de los vencedores. ¿Será acaso mi destino?” (199). However, she will not become an Andromache (Hom. Il. 6.450-465), but a Creusa (Verg. Aen. 2.785-788): she will die rather than be taken hostage.

The Aeneid's Dido is modelled on different figures from the Trojan epic cycle, especially the Odyssey ${ }^{17}$ : she is both a steadfast Penelope, besieged by the suitors, and an alluring Calypso, who retains the hero; she also recalls the Phaeacian royal family (Nausicaa, ${ }^{18}$ Alcinous, Arete), as a welcoming and generous hostess. For the contemporary first-century Roman reader, she would have clearly resembled Queen

\footnotetext{
14 Significantly, when seeing the nomadic women, Aeneas remembers the women of Troy (50).

15 See Lauriola (2015, 76-89).

16 A similar appreciation is made by Le Guin's Lavinia: "His eyes are full of fire, smoke and fire, because he saw his city burn" $(2009,154)$.

17 Cairns (1989, 134), Rivero et al. (2009, vol. 1, LXV-LXVI). For the literary sources and models for Virgil's Dido, see also, amongst others: Pease (1935, 11-29), Horsfall (1995, 133-134), Weeda (2015, 133-135), Quint (2018, 69).

18 Cairns (1989, 131-134).
} 
Cleopatra. ${ }^{19}$ A twenty-first century readership may see Vallejo's Elissa more like a Daenerys Targaryen ${ }^{20}$ : an exotic queen across the Narrow Sea, ${ }^{21}$ loyal to her dead husband (Khal Drogo), exiled, barren, fluent in many languages, protected by three warriors ("bloodriders"), powerful against all odds, she eventually falls fatally in love with a troubled hero (Jon Snow), and is killed by his dagger. Elissa resembles Khaleesi, save for one detail: her age.

"Elisa no está en la flor de la edad" (39), declares Eros, somewhat euphemistically: in fact, Elissa is constantly troubled by her being older than Aeneas, ${ }^{22}$ and as unwilling to show herself naked before him as she is tormented by an unfulfilled maternity instinct. ${ }^{23}$ By focusing on her anxieties, Elissa's being older than Aeneas adds a new twist to the frustrated love story ${ }^{24}$; at the same time, the question of aging links her with different versions of Penelope, ${ }^{25}$ with whom she shares her astuteness, highlighted by Eros (57), ${ }^{26}$ and the pressing siege of her suitors. ${ }^{27}$ Additionally, by transferring mystical powers to Anna, ${ }^{28}$ Irene Vallejo's Elissa is not as dreadful as Dido, but more complex, subtly anguished and overtly vulnerable. Just like the protagonist in Buero Vallejo's play, La tejedora de sueños, she is a dreamweaver, whose hopes are shattered: "todas nuestras esperanzas están tejidas con humo" (186).

\footnotetext{
${ }_{19}$ Cairns (1989, 57), Horsfall $(1995,134)$, Hardie (2014, 57), Weeda (2015, 135-137), Quint (2018, 76-77).

${ }^{20}$ A central character from G. R. R. Martin's saga A Song of Ice and Fire (1996-) and Benioff and Weiss' Game of Thrones (2011-2019), the HBO adaptation of the novels.

${ }^{21}$ Carthage noticeably reverberates in Qarth, one of the cities she conquers. For the influence of Carthage on Game of Thrones, see Gorzelany \& Matusiak (2016, especially 124-127).

22 This unequal love relationship is the opposite of the one in Le Guin's Lavinia, where Aeneas is double the age of Lavinia, as was frequent in antiquity; but in both narratives attention is paid to the couples' sexual encounters and the hero's innate sexual capacities.

23 84; Verg. Aen. 4.327-330.

${ }^{24}$ Whereas some critics argue that the Virgilian Dido must be a mature or middle-aged woman, Clausen prefers to picture her as young: "Imagine Dido as a young woman, not much older than Medea or Arete: the pathos of her story is increased, and the allusions in Aeneid 4 to Catullus's Ariadne, a maiden princess seduced and abandoned by an adventurer from over the sea, become more appropriate" $(2002,211-$ 212). Vallejo's option, however, increases her frustration: a girl is more easily deluded by romantic love. This twenty-first century Elissa is closer to Tennessee Williams's Blanche Dubois than to Catullus's Ariadne.

${ }^{25}$ Penelope is rejuvenated at the end of Homer's Odyssey (Hom. Od. 23.187-196); Ovid's Penelope ends her letter to her husband with a remark on the passage of time (Ov. Her. 1.116 facta videbor anus); Antonio Buero Vallejo's is ten years older than Anfino, with whom she is secretly in love, and acknowledges that both she and Odysseus are old (1996, 202-203); Atwood's heroine also hints ironically at the ravages of old age: “'We're not spring chickens anymore,' I said" (2005, 172). Elissa also recalls Atwood's and Buero Vallejo's Penelope in her jealous fascination with Helen of Troy: "En su interior imagina la belleza fabulosa de Helena" (Vallejo Moreu 2015, 39); "Para Eneas la bella Helena es una ficción más de su conmovedor cuento sobre Troya" (40). In The Penelopiad, Penelope's feud with her cousin is a recurrent motif; in La tejedora de sueños her envious hatred of Helen gives Penelope a reason to live (Buero Vallejo 1996, 123, 197).

${ }^{26}$ For Dido's shrewdness in the Aeneid, see Verg. Aen. 1.365-368.

27 "No me engaño, sé que están absorbidos por el deseo de poseerme y ocupar el trono" (15).

28 Virgil's Dido was partly modelled on the sorceress Medea (Cairns 1989, 135; Clausen 2002, 75-76).
} 


\section{Aeneas}

Dissent and the challenging of authority are not absent in the Aeneid, although it is normally the gods who are to blame: Iris, for instance, is sent to the Trojan women in Book V and urges them to burn the fleet in order to stay in Sicily. In the novel, the hero knows that his men are tired, and that his leadership should not be taken for granted: "Me llaman perro y escoria" (10). He is not happy with himself either: the phantoms of the past come to haunt him once and again, filling him with regret (33). One of his troubling memories is Creusa, his dead wife, inexplicably lost while fleeing from Troy. In the Aeneid she appears to him as an unreproachful ghost; in El silbido del arquero, Elissa is told the same official version, but it is the god Eros who undermines and questions it:

¡Qué mentiras tan entretenidas! A los dioses nos provoca risa, y a la vez nos fascina, escuchar cómo relatan los mortales sus propias vidas. Casi sin querer, la fantasía empieza a rellenar los huecos que abren los remordimientos y el olvido (41). ${ }^{29}$

Every reader of the Aeneid has surely felt perplexed by the fact that Aeneas saves his son and father, whom he carries on his shoulder, but loses his wife on the way. Eros hits a raw nerve here, but he has an explanation: fantasy fills in the gaps left by remorse and oblivion. He knows but does not reveal the hero's secret. Later, while Aeneas cleans the wound of a nomadic woman taken hostage in one of his raids, he recalls Creusa's adultery and his killing of the rival: "Desde ese día ella me tuvo miedo y yo la odié" (81). Their mutual rancour is a heavy burden to shake off, but Elissa's embraces can help him erase his troublesome marriage (105). In her arms, he can take a rest from being himself $(71,105)$ : he can stop being a literary hero and start feeling like a man.

Yet he needs to feel like a hero. Despite his unwillingness to attack the nomadic tribes (70), he razes their "poblado de cabañas" (49) and slaughters its inhabitants; he does his duty: "Quiero creer que hoy he cumplido con mi difícil deber [...] enseñar a estos pueblos nómadas, sin ciudades ni leyes, a respetar la justicia” (74). Vallejo subtly exposes the moral superiority of the conquerors, of the victors, the outrageous façade of colonialisation as an imposition of civilisation. ${ }^{30}$ However, for Aeneas, he has not done the right thing. Although he wants to believe, remorse-he may have killed the nomadic woman's man-prompts him to implore the gods to grant him "un pequeño territorio donde empezar una vida limpia de injusticias y profanaciones" (82). This wish is apt to provoke bitter grinning in Virgilian readers, since the roots of Rome go back to the brutal wars described in Books VII-XII of the poem. Aeneas's sallying to attack the nomadic tribes, an insightful amplification

\footnotetext{
${ }^{29}$ Eros also notices, to his astonishment, Aeneas's omission of the fact that "Troya era una ciudad estratégica" (39) in his account to Elissa. However, Elissa's version of her past is also partial and distorted (130), as observed by the god.

${ }^{30}$ Thus she is attuned to the mostly pessimistic view of the Aeneid propugned by the so-called "Harvard school"; see Harrison (1990, 5).
} 
apparently modelled on some passing remarks in the Aeneid, ${ }^{31}$ tinges his epic characterisation with bitterness. "Why is he a hero?", asks Le Guin's Lavinia to Virgil's shadow, overwhelmed by his account of Aeneas's brutal killings in the wars for Latium: "Because he does what he has to do" $(2009,94)$, replies the poet categorically. Being a hero is thus no mean task. From the very beginning, Vallejo undermines naive notions of heroism by offering a realistic approach to his feelings, doubts, traumas and to the language of self-delusion: this Aeneas also does what he must and tries to justify it, often resorting to religion.

\section{Religion, Language and Self-delusion}

In the classical epic tradition, gods intervene in the plots, taking sides, helping their protégées, even taking arms when necessary. They meet to discuss human affairs in assemblies presided by Zeus/Jupiter and go to the earth to talk to mortals, in disguise, sometimes revealing their identities, both willingly and inadvertently. No fewer than five gods and goddesses appear in Book I of the Aeneid: Juno, Neptune, Venus, Jupiter, Mercury. Throughout the epic poem, many more deities, both Olympian and minor ones, interact with humans by taking their shapes, sending messages or messengers or simply through their power over nature. This fascinating divine apparatus $^{32}$ is not present in Vallejo's narrative, except for the god of love. There are no gods quarrelling, no goddesses protecting or attacking the Trojans, no divine messengers: everything but love is reduced to human proportions.

Religion, however, is not absent in the novel: on the contrary, sacrifices, auguries, prayers $^{33}$ are part of the everyday life of both Tyrians and Trojans and determine their interactions, desires and decisions, as well as their interpretation of nature and existence. Thus, whereas in Book I of the Aeneid it is Aeolus, following the orders of Juno, who provokes the storm and the Trojan fleet's shipwreck, here the tempest is simply a tempest, even though Anna imagines the hand of a god as black clouds gather ("algún dios debía tenerlas sujetas", 13): likewise, when Elissa ponders on their parallel lives, she sees the operations of divine providence ("Algún dios ha traído a Eneas hasta mis costas", 88), which the hero will later endorse ("Los dioses quisieron traerme ante ti", 130).

Venus is a latent presence: she is remembered as the mother of Aeneas, who prays for her help, but she is not the Virgilian character desperately seeking protection for her son from lurking menaces, normally orchestrated by Juno. She is more Lucretian than Virgilian. In fact, the hero's prayers recall the beginning of De rerum natura ${ }^{34}$ :

\footnotetext{
31 At the beginning of Book IV of the Aeneid, Anna advises her sister Dido that she should take Aeneas as an ally (and lover) because they live amongst bellicose and savage tribes, such as the Gaetulians and the Numidians (Verg. Aen. 4.40-44).

32 See the comprehensive analysis in Coleman (1982).

33 This especially applies to pious Aeneas ("arrodillado junto a la hoguera, hablo con los dioses", 18).

34 Lucretius, De rerum natura $1-10$.
} 
Madre, placer de dioses y hombres, estrella de la tarde, por ti nacen los animales, de ti huyen los vientos, la tierra da flores suaves para ti, ríe contigo el mar, brilla la luz en el claro cielo. Diosa de la sonrisa eterna, ayúdame a encontrar a Yulo (32). ${ }^{35}$

On seeing a statue of a goddess, probably Astarte, Aeneas wonders whether gods are amongst mortals, watching them, unseen through some godlike contrivance (30). However, it is not Venus who watches him without being seen, but rather his halfbrother Eros, eager to unite Aeneas and Elissa. His physical presence goes hardly unnoticed, constantly running the risk of being discovered. His well-intentioned efforts are, at best, unforeseen, if blatantly ineffective; yet this contributes to the building up of an overall sense of dramatic irony, as a credulous, god-fearing Aeneas fails to grasp the scale of Eros's unfruitful endeavours while he is blindly intent on his vain hopes and beliefs.

Strictly speaking, Aeneas constantly asks the gods for guidance and performs rites scrupulously, religiousness being one of his most conspicuous traits (hence his famous epithet pius). In classical literature, the gods' will is usually ungraspable, oracles are ambiguous, often misleading, and men have to collaborate by using their intelligence (132). There is a sense of urgency in his willingness to believe that all his decisions are dictated and sanctioned by divine forces, which more often than not amounts to self-delusion; he constantly imposes on everyone and everything his own self-centred way of interpreting anything that happens to him. Thus, if Iulus is happy in Carthage, Aeneas wonders whether the gods speak to him through his son (121); he believes that they have taken him to Elissa (130), and invited him to stay (142); after all, Troy will be where the Trojans are: "Troya somos nosotros. Troya renacerá donde vivamos" (142). ${ }^{36}$ And yet, when Anna speaks to him in a trance in the Temple of Eshmun, he misconstrues what she tries to convey. The girl wants him to take her and Elissa out of Carthage; he resolves to leave, but only with the Trojans, convinced that it is the wish of the gods who protect him (178): ironically enough, it is not a god, as in the Aeneid, who tells him simply to go (Aen. 4.237 naviget); it is a desperate girl, eager to sail from an oppressive city. In this epiphanic moment, it is paradoxically the shadow of Creusa, her persistent, grudging, remorseful memory, that makes the hero abandon Elissa.

The queen does not believe that a god has ordered him to leave: "Cada uno llama dioses a sus propios deseos" (184). This sententious remark is taken from an unrelated context of the Aeneid, ${ }^{37}$ but it solemnly preludes her death. Her interpretations are those of a woman's-pressure is being brought to bear on her to marry, but she will not choose just anyone; Aeneas, however, "interpreta todo en términos épicos" (184), as a hero, observes Eros. Rather than full-fledged delusions, which indicate

\footnotetext{
35 Venus is seen, thus, as a natural force and as the planet, the evening star (see also 36-37). A similar approach can be found in Le Guin's novel (2009, 68-69): Virgil quotes the preface of De rerum natura to assure Lavinia that her non-anthropomorphic conception of the goddess Venus is right.

36 An echo of Martial's epigrams: 10.13.10 In quocumque loco Roma duobus erit.

37 Verg. Aen. 9.185 an sua cuiqui deus fit dura cupido? These are the words of the ardent Nisus, who will be brutally killed afterwards together with his friend Euryalus.
} 
"an abnormality in the affected person's content of thought" and involves a false belief taken at face value, without a shade of "doubt as to its truthfulness" (Kiran \& Chaudhury, 2009, 3), the misgivings and mild uncertainty that may inform the lovers' beliefs are negated by leaps of faith in their own introspective narratives. Relentless fate and the constraints of patriarchal politics and tradition ${ }^{38}$ - two insurmountable occluding forces-respectively dictate and feed their every move and mounting desire, just like Virgil feels obliged "a ser fiel a la leyenda"; for months, he has struggled with himself "por dar a Eneas y a Elisa, a Ana y Yulo, un final más dulce, más clemente", but unfortunately he has been denied "el libre vuelo de la imaginación" (205). Mutual understanding is nowhere near possible when two people have different interpretative codes, a situation that lies at the heart of the human condition. Their untenable choice is therefore contingent on Virgil's dutybound, unimaginative one. The subversive function of Vallejo's rewriting of the story is placed in the foreground as we gradually realise that Aeneas the man has been annulled by Aeneas the hero, ${ }^{39}$ and Elissa the woman by Elissa the queen, and neither the god of love nor the poet can do anything to change the course of destiny and prevent everyone's share of misfortunes and disillusion.

Trojans and Tyrians have different mother tongues ${ }^{40}$ : they do not understand each other. And with unintelligibility comes suspicion and distrust. Unlike other writers who overlook this matter, ${ }^{41}$ Vallejo pays much attention to language, communication and misunderstanding in this novel, to the extent that it can be considered as one of its key themes. Significantly enough, Eros is puzzled by the incapacity of humans to understand each other across languages as gods do (40), and he takes advantage of this in his love scheming (90). When Aeneas is in the presence of Carthaginians for the first time, he notes their strange language (18), which evokes a feeling of estrangement and danger. Yet he can communicate with the queen, since both speak Akkadian, the "lengua franca" of kings $(25,90)$. Their mutual intelligibility provokes a side effect in her people, who are left out and start to distrust them: "El extranjero ha conseguido separarme de mi pueblo con las barreras de un idioma que solo nosotros comprendemos" (24), reflects Elissa during their very first encounter. Only her sister Anna can understand them (25) and join their coterie (41), their "espacio propio" (90). Yet speaking the same language does not ensure mutual understanding: language can be one's homeland, but also a land of exile and "lenguas exiliadas" (33). Their communicative failure is of the utmost importance in

\footnotetext{
38 Eros divulges Elissa's epiphany when she summons Aeneas to the palace, a scene filled with "ideales y tiernas utopías" in which she makes "un descubrimiento, el amor entendido como placer de la sublevación. ¿No es Cartago un nuevo mundo? ¿Sería posible aquí una vida que no reprima sus sentimientos naturales, que no la someta a la tiranía de las costumbres?" (93).

39 "But why does Aeneas never tell Dido of his love? Because he cannot; he is inhibited by epic decorum, by the tradition in which he moves and has his being. Passionate love on the man's part can be expressed in comedy, elegy, and pastoral, but not in epic" (Clausen 2002, 88).

40 "Nos rodean gritando en una lengua extraña" (20); "Los prisioneros no entienden mis palabras" (22).

41 In Le Guin's novel, Lavinia is surprised that everyone in her account communicate in Latin, Virgil's language. What is more, Greek, Trojans, Tyrians, Latins and Etruscans understand each other in the Aeneid and no reference is made to different languages until the end of the poem, when Jupiter promises Juno that the new people will keep the language of Latium (Verg. Aen. 12.825; 834; 837).
} 
Virgil's poem: Dido and Aeneas give different names to their relationship. For her, it is not a furtivum amorem (Aen. 4.271), but a coniugium (172), a marriage; yet Aeneas has never offered her the ritual torches that symbolise a legal union: nec coniugis unquam / praetendi taedas (338-339). ${ }^{42}$ Vallejo's characters also interpret their affair in irreconcilable ways. The storm lightnings evoke for her the marital torches, but she knows that this is "una idea extraña" (109); on his departure, Aeneas tells her that he never promised her anything (193). Eros himself recognises his own incapacity to overcome this breach in the lovers' expectations, while reflecting on the efforts of humans to accommodate reality to their desires through language:

¿Y qué hacer cuando ellos mismos construyen sobre el cimiento de un malentendido y fingen no darse cuenta? Elisa llama juramento a su unión en la cueva, aunque ningún juramento fue pronunciado. ¿Por qué? Porque necesita pensar que los actos de Eneas equivalen a una promesa, la promesa de permanecer a su lado para siempre. Juramento... Las palabras de los efímeros mortales son en el fondo conjuros para que se cumplan sus deseos (133).

When hearing him dream-talking in his language she recognises that, deep down, he is unreachable, "es un mar vedado" (136): Elissa's interpretations are also strongly driven by self-delusion.

Vallejo builds up this multiplicity of limited - and even conflicting-perspectives of the same events so as to provide a wider overview, which ironically eludes even Eros. It is precisely the god who pinpoints the unreliability of their self-narratives, how they "fantasean" (90), especially in love matters, stressing the efforts required to understand Aeneas, to pierce "la cubierta de quitina de este selecto crustáceo humano" (90). Therefore, the reader must gradually assemble all subjective fragments and jarring notes taken from all directions to fully sound the depths of tragedy. Other than Virgil, who finally reconciles his yearning with his duty by endowing his work with his selfless "esperanzas" (205), the other four point-of-view narrators succumb to their unfounded certainties and ill-gotten illusions. These leaps of faith are but dream-weaving exercises which end up as mild episodes of cognitive dissonance for Eros, or as faits accomplis, to the baffling frustration of all the rest, who witness their dreams go up in smoke. At its most intense, dramatic irony subtly emerges out of two pairs of contiguous chapters. The first pair highlight how the memories of the lovers' first sexual encounter in the cave do not coincide $(106,108)$; the second two consist of Anna's oracle and Aeneas's subsequent misinterpretation of her plea. Vallejo constructs mirror-like responses which make their contradictory views clear to the reader, while the characters themselves remain completely oblivious to each other's thoughts.

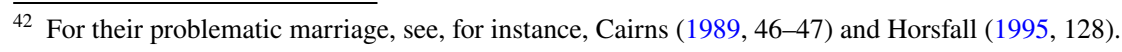




\section{Carthage and Rome: The City as Symbol of Corruption and Paralysis}

Carthage, understood as a synecdoche for human inextricability-that Eros finds so puzzling-, is afflicted by moral and physical stagnation. This all-embracing anomaly, projected in terms of confusion and misunderstanding, had already, almost imperceptibly, been laying the groundwork for tragedy even before the Trojans' arrival. The true Tyrian currency, as we painstakingly learn, is obstruction, while its market is a lifeless simulacrum of civilisation scourged by a real and figurative blight, a "secreto sobre la ciudad" that Anna reveals to Iulus:

La ciudad está maldita. Cartago es una ciudad maldita [. . .] Por eso los que viven aquí pierden los dientes. Por eso los árboles se secan y dejan de dar frutos, como esta higuera, de la que ya nunca nacerán higos dulces. [. . .] hay horribles plagas de escorpiones que salen de todas partes e invaden las casas, las calles, los campos. Por eso los únicos niños somos tú y yo. Las mujeres de esta ciudad son estériles, aquí no nacen niños (138).

Tooth loss may stand as an emblem of corruption or as a lack of identity. Paradoxically, despite being associated with children and the elderly, whose teeth fall out naturally, it is the rest of the population who lose their teeth. Infertility in Carthage contrasts with the fertility of the nomadic tribes outside its walls (71). Little else is revealed or hinted at about the origins of this plague-like disease, which reinforces its open-ended symbolic signification. It seems clear, however, that gods cannot be held responsible, even though Anna insists that the city is under a curse. Trees wither and dry out, from roots to top, an image of family decline rendered all the more conspicuous by the absence of fruits, which parallels that of children. Without offspring and devoid of the wisdom and accumulated communal memories of old age, Vallejo stretches the notion that Carthaginians are responsible for their own actions; and, at the same time, she underscores how Virgil becomes reconciled to his lack of creative freedom by reaching a compromise between duty and hope when writing the fictional Aeneid.

This Vallejian Carthage and its anomalies, mainly seen through the perceptive eyes of Anna-a child, an anomaly herself-is largely a proper reflection of the Rome depicted in the Virgil chapters in the peripatetic mode. ${ }^{43}$ Just like scorpionridden Carthage, he is besieged, blockaded and haunted in his sleep and in his urban strolls. Scorpions - incidentally, the name of a Roman siege engine-are nocturnal venomous arachnids which paralyse their victims with their sting; here, these predatory arthropods are also an anticipatory intimation of death. Virgil's angst and creative blockage, as well as his sickly constitution, mirror the symptoms and effects of the malady that figuratively afflicts both cities; the Rome Virgil sees and where he feels unable to write the Aeneid is the sordid city of later poets, Martial and Juvenal (Martino, 2017, 207-208), whose satirical eyes expose its manifold hidden corruptions and grotesque pretence.

\footnotetext{
${ }^{43}$ For the gender implications and articulation of this roaming perspective, see Nord (1991); see also Wallace (1993) for its rural associations with Virgilian pastoral.
} 
This straightforward emphasis on the urban space as the irradiating repository of social ills is a literary trope. Therefore, it is harnessed not only in the classics, but also in countless narratives falling within the wider scope of the novel tradition, encompassing Galdos's and Baroja's Madrid; Dostoevsky's Saint Petersburg; Balzac's and Zola's Paris; or García Márquez's Macondo. The negative influence exerted by this accursed Carthage on its dwellers is reciprocal: it emanates from them and finds its own vindictive way back, a pattern of barren recirculation and occlusion suggestive of Charles Dickens's representation of London in Dombey and Son (1846-1848) and especially Bleak House (1852-1853). ${ }^{44}$ Like them, El silbido del arquero is a narrative of contagion that delves, amongst other antagonismssuch as teleology and free will—, into the polarity of health and disease; it invests the depiction of the latter, in a Bakhtinian inversion, with "positive cultural value [...] to cure the false health that masks the cultural disease "canker[ing] the hearts of men" (Christensen, 2005, 1). Anna is endowed with a child's breadth of vision, and is capable of penetrating falseness, hypocrisy and corruption. When contemplating the grotesque, she unfailingly feels an oxymoronic fascination with repulsion. ${ }^{45}$ This links her to an illustrious group of Dickensian characters-especially children, such as Nell Trent, Paul Dombey, David Copperfield or Oliver Twist-whose enhanced imagination allows them to read beyond adult veils. The latter becomes patently obvious when, innocently playing hide and seek with Iulus, inside a large amphora, she accidentally witnesses the disclosure of the secret plot to assassinate Aeneas: "No hay en todo palacio un lugar mejor para esconderse que este: la gran vasija agrietada de la despensa" (162), she says, stressing her own natural inclination to hide, watch unobserved and eavesdrop. From her vantage point, she can see through the cracks.

las vigas oscuras, de las que penden ganchos con reses desangrándose. Por los cuerpos abiertos en canal resbalan oscuras gotas, y caen, y alrededor danzan las moscas, negras y golosas, con monótono bordoneo (163).

The morbid contemplation of this gory view does not only evoke the murder of the councillors, Aeneas's failed assassination or the bloodshed of Troy, but it also anticipates Elissa's stabbing herself, the coming of Iarbas and the future Punic Wars between Rome and Carthage. But this macabre still life is just paving the way for the contrary impulses provoked by further grotesque imagery:

la rendija me permite ver los pies de un hombre [. . .]. Unos dedos velludos asoman entre las tiras de las sandalias. No puedo apartar la vista de ellos, fascinada por el asco, estremeciéndome a causa de un mal agüero. Imagino que

\footnotetext{
44 In it, London "is a cancerous wen, which threatens to engulf the world and perhaps extinguish human life altogether" (Schwarzbach 1979, 114).

45 Not only does this irreconcilable duality embrace Walter Pater's appreciation of the "'fascination of corruption", of the "diseased faces" of Leonardo and the Medusa (Christensen 2005, 3), but it also summarises Dickens's life-long relationship with London and his stylistic propensities to the rhetoric and aesthetics of the grotesque; see, for example, Hollington (1984), Stone (1994, 564), and Allen (1999).
} 
una fiera, erguida sobre sus patas traseras, merodea olfateando mi escondrijo (163).

However, Anna's ordeal is far from over. She stares at Iulus in amazement, who, undetected by the plotters while they agree that "la tierra se tiña con la sangre del troyano" (164), though innocently unaware of the danger he is in,

se acerca a un gran buey despellejado que cuelga de un gancho, oscurecido por el revoloteo de una nube de moscas. Varias gotas de sangre tiemblan en las entrañas del buey antes de salpicar la cara de Yulo, que sonríe y levanta las manitas en el aire bajo la suave llovizna (164).

Vallejo's text also shows elements in common with these and other novels of familial decline, social decadence and degeneration-physical, cultural and moral-, since a growing lack of births or children is a recurrent topos in speculative, mostly dystopian, fiction such as Brian Aldiss's Greybeard (1964), P. D. James's The Children of Men (1992) or Margaret Atwood's The Handmaid's Tale (1985) and MaddAddam trilogy (2003-2013). No children-or fertile womenmeans death, and even worse, extinction. In Dickensian London, "the ubiquity and unavoidability of urban filth and disease-generating miasma" (Choi, 2001, 562) manifests itself through smog, mud, squalor, smallpox or tuberculosis. For its part, however, the monstrous many-eyed Fame becomes but another injurious sign of the deeply ingrained anomaly that devastates Carthage: in narrative terms, contagion is mainly represented both by the symptomatic nonexistence of upper and lower age-groups and their related cultural roles, and by the highly contagious essence of Fame, spreading like wildfire and leaving a trail of destruction and dehumanisation in its wake. Furthermore, on a more personal scale, the either unfathomable or irresolvable consequences of the interdependence of subjective experience are presented as a chain reaction. All five characters are frustrated in their fragile castaway dreams (206) and elusive desires to sacrifice "la fundación de Roma a cambio de la dicha de unos amantes y los juegos de unos niños" (205) and emerge unscathed from the wreck: "la derrota es el punto de partida de una gran historia" (204), concludes Virgil.

Funding Open Access funding provided by Universidad Pablo de Olavide/CBUA thanks to the CRUECSIC agreement with Springer Nature.

Open Access This article is licensed under a Creative Commons Attribution 4.0 International License, which permits use, sharing, adaptation, distribution and reproduction in any medium or format, as long as you give appropriate credit to the original author(s) and the source, provide a link to the Creative Commons licence, and indicate if changes were made. The images or other third party material in this article are included in the article's Creative Commons licence, unless indicated otherwise in a credit line to the material. If material is not included in the article's Creative Commons licence and your intended use is not permitted by statutory regulation or exceeds the permitted use, you will need to obtain permission directly from the copyright holder. To view a copy of this licence, visit http://creativecommons.org/licen ses/by/4.0/. 


\section{References}

Allen, R. (1999). John Fisher Murray, Dickens, and 'the attraction of repulsion.' Dickens Quarterly, 16(3), 139-159.

Atwood, M. (2005). The Penelopiad. Canongate.

Baquero Goyanes, M. (1984). Virgilio, personaje literario. Simposio virgiliano: Conmemorativo del bimilenario de la muerte de Virgilio (pp. 9-26). Universidad de Murcia.

Buero Vallejo, A. (1996). La tejedora de sueños. Llegada de los dioses. Edición de Luis Iglesias Feijoo. Cátedra.

Bugada, G. (2019). Audire et reddere voces. La traducción como diálogo y translatio en Lavinia de U. Le Guin. Liburna, 14, 67-81.

Cairns, F. (1989). Virgil's Augustan epic. Cambridge UP.

Cantó Llorca, J. (2016). La voz de Lavinia. In De la Villa, J., \& Falque, E. (Eds.), Augusto en la literatura, la historia y el arte con ocasión del bimilenario de su muerte, Estudios Clásicos, Número extra (Vol. 3, pp. 35-54).

Choi, T. Y. (2001). Writing the Victorian city: Discourses of risk, connection, and inevitability. Victorian Studies, 43, 561-589.

Christensen, A. C. (2005). Nineteenth-century narratives of contagion: 'Our feverish contact.' Routledge.

Clausen, W. (2002). Virgil's Aeneid. Decorum, allusion and ideology. K. G. Saur.

Coleman, R. (1982). The gods in the Aeneid. Greece \& Rome, 29(2), 143-168.

Cox, F. (2011). Sibylline Sisters: Virgil's presence in contemporary women's writing. Oxford UP. https:// doi.org/10.1093/acprof:oso/9780199582969.001.0001

Cristóbal López, V. (2002). Dido y Eneas en la literatura española. Alazet: Revista de Filología, 14, 41-76.

Cristóbal López, V. (2015). Lavinia de Ursula K. Le Guin, una novela virgiliana. Cuadernos de Filología Clásica. Estudios Latinos, 35(2), 363-376. https://doi.org/10.5209/rev_CFCL.2015.v35.n2.51105

Farrell, J., \& Putnam, M. C. J. (2010). A companion to Vergil's Aeneid and its tradition. Wiley-Blackwell. Gaylin, A. (2004). Eavesdropping in the novel from Austen to Proust. Cambridge UP.

Gorzelany, D., \& Matusiak, P. (2016). Carthage imagined: from Giovanni Pastrone's 'Cabiria' (1914) to 'Game of Thrones' (2012). Collectanea Philologica, 19, 117-128. https://doi.org/10.18778/17330319.19.10

Hardie, P. (2014). The last Trojan hero: A cultural history of Virgil's Aeneid. I. B. Tauris. https://doi.org/ 10.5040/9780755693900

Harrison, S. J. (1990). Some views of the Aeneid in the twentieth century. Oxford readings in Vergil's Aeneid (pp. 1-20). Oxford UP.

Hollington, M. (1984). Dickens and the grotesque. Croom Helm.

Horsfall, N. (1995). A companion to the study of Virgil. Brill.

Kiran, C., \& Chaudhury, S. (2009). Understanding delusions. Industrial Psychiatry Journal, 18(1), 3-18.

Lauriola, R. (2015). Trojan women. In R. Lauriola \& K. N. Demetriou (Eds.), Brill's companion to the reception of Euripides (pp. 44-99). Brill. https://doi.org/10.1163/9789004299818_004

Le Guin, U. (2009). Lavinia. Gollancz.

Lida de Malkiel, M. R. (1974). Dido en la literatura española: Su retrato y defensa. Tamesis.

Martino, L. M. (2017). Irene Vallejo Moreu, El Silbido del arquero. Revista de Estudios Clásicos, 44, 205-210.

Nisa Cáceres, D., \& Moreno Soldevila, R. (2020). 'A dream within a dream': Liminalidad y creación poética en Lavinia de Ursula Le Guin y El silbido del arquero de Irene Vallejo. Cuadernos de Filología Clásica. Estudios Latinos, 40(2), 345-366. https://doi.org/10.5209/cfcl.73012

Nord, D. E. (1991). The urban peripatetic: Spectator, streetwalker, woman writer. Nineteeth-Century Literature, 46(3), 351-375.

Pease, A. S. (1967-1935). Publi Vergili Maronis Aeneidos Liber quartus. Wissenschaftliche Buchgesellshaft.

Quint, D. (2018). Virgil's double cross. Design and meaning in the Aeneid. Princeton UP.

Rivero, L., Estévez, J.A., Librán, M., \& Ramírez de Verger, A. (2009-2011). Publio Virgilio Marón, Eneida. C.S.I.C. Tirant lo Blanch.

Schwarzbach, F. S. (1979). Dickens and the city. Athlone.

Stone, H. (1994). The night side of Dickens: Cannibalism, passion, necessity. Ohio State UP.

Vallejo Moreu, I. (2015). El silbido del arquero. Contraseña. 
Vallejo Moreu, I. (2019). El infinito en un junco. La invención de los libros en el mundo antiguo. Siruela. Wallace, A. D. (1993). Walking, literature, and English culture: The origins and uses of peripatetic in the nineteenth century. Clarendon.

Weeda, L. (2015). Vergil's political commentary in the Eclogues, Georgics and Aeneid. De Gruyter. https://doi.org/10.1515/9783110426427

Publisher's Note Springer Nature remains neutral with regard to jurisdictional claims in published maps and institutional affiliations. 